\title{
João Cândido 1910-1968: arqueologia de um depoimento sobre a Revolta dos Marinheiros
}

\author{
José Miguel Arias Neto*
}

\section{Introdução}

De HÁ MUITO OS HISTORIADORES procuram construir análises acerca dos documentos que empregam em seus trabalhos. Desde o memorável lançamento da De Re Diplomática, de Mabillon, que instituiu definitivamente a crítica documental (Bloch, 1997, p. 123) até o aparecimento da obra $A$ arqueologia do saber, de Michel Foucault, grandes transformações se passaram na arte de abordagem do documento histórico. Como observa Le Goff (1984, p. 95), o termo latino documentum era derivado de docere (ensinar) e evoluiu para o significado de prova no século XIX. Atualmente os historiadores deixando de considerar documentos e arquivos como elementos aleatórios e percebendo neles as relações de poder das sociedades que os produziram, passaram a analisá-los enquanto monumento, ou seja, como montagem que é preciso desmontar através do estudo de suas condições de produção (Le Goff, 1984, p. 104).

Estas observações sumaríssimas permitem entrever vários problemas quando nos deparamos com documentos orais. Em primeiro lugar cabe destacar que o documento oral não tem sequer a enganosa aparência de naturalidade que pode envolver outros documentos escritos: uma entrevista ou um relato de vida é sempre provocado pelo

* Professor do Departamento de História da Universidade Estadual de Londrina. 
pesquisador ou pela instituição ao qual este está ligado. Contudo, como nos demais documentos, nem sempre as intenções do pesquisador ou da instituição são manifestadas, ou mesmo, o próprio processo de construção da entrevista pode conduzir a resultados distintos dos esperados. Como já observado por inúmeros teóricos, um depoimento sempre se constitui a partir de relações de poder entre os participantes do processo. Neste sentido, um documento oral, exige, como qualquer outro, uma análise crítica que verifique: a) as intenções do pesquisador, isto é o lugar e a conjuntura histórica de produção da entrevista; b) sua condução, ou seja, o universo ideológico de entrevistador e entrevistado, seus conflitos e superposições; c) os resultados obtidos através de sua realização, isto é, a hierarquia das idéias resultantes do processo e o seu lugar na historiografia que aborda a questão proposta.

\section{Do lugar de produção e da conjuntura}

A entrevista de João Cândido foi realizada para o ciclo de História Contemporânea do Museu da Imagem e do Som do Rio de Janeiro, a 29 de março de 1968 (Depoimento de João Cândido, 1968, 1). Data tida como emblemática, 1968 foi o ano das grandes manifestações contra a guerra do Vietnã, pela reforma do sistema educacional francês, pela liberação sexual. No Brasil, o mês de março de 1968 se iniciou com a morte do estudante Edson Luís pela Polícia Militar do Rio de Janeiro. Também neste ano, a ALN, o MR8, a VPR, entre outras organizações de esquerda, iniciaram as primeiras operações armadas contra o regime militar, instaurado em 1964. Em 1968, o governo Costa e Silva, representando a "linha dura" entre os militares já havia afastado o chamado "grupo da Sorbonne", mais moderado, do poder. Realizava-se um contra-golpe dentro do golpe. Em dezembro, ou seja, alguns meses depois da entrevista de João Cândido, foi editado o Ato Institucional número 5, o AI-5, através do qual o Congresso foi fechado, estabelecido o poder presidencial para cassar mandatos e suspender direitos políticos, suspenso o babeas corpus para os acusados de crime contra a segurança nacional e contra a ordem econômica e social. Em 1968 fazia quatro anos que a "Rebelião dos Marinheiros" havia sido derrotada e a Associação dos Marinheiros e Fuzileiros Navais do 
Brasil (AMFNB) desbaratada com prisões, perseguições e expulsões de seus integrantes. De acordo com Capitani (1997) a Associação, além de lutar pelos direitos dos marinheiros, procurou atuar no sentido de neutralizar a participação dos comandos da Marinha no golpe contra o governo que se sabia estar planejando. Os marinheiros punidos pela Rebelião de 1964 até hoje não foram anistiados.

Surgida em março de 1962, a Associação, durante a primeira fase de sua existência, isto é, até 1964, vivenciou um conflito interno aparentemente insuperável: havia uma corrente mais conciliadora que desejava reformas na Marinha a partir da colaboração entre oficiais e marinheiros e outra mais combativa, que propunha uma orientação mais independente (Capitani, 1997, p. 23). De acordo com o mesmo autor, foi a inflexibilidade do Almirantado que terminou por conduzir a Associação para propostas mais radicais, ao mesmo tempo em que estabelecia laços de solidariedade mais fortes com outras Associações de Militares. Atraída pelo trabalhismo do Presidente João Goulart, a AMFNB articulou-se cada vez mais a movimentos militares e populares como as ligas camponesas, associações de sargentos, suboficiais e policiais militares, a Frente de Mobilização Popular e a Frente Parlamentar Nacionalista. No dia 24 de março, o ministro da Marinha ordenou a prisão dos dirigentes da Associação, sob o pretexto de que estes haviam subvertido a hierarquia durante as comemorações de aniversário da AMFNB. O ministro proibiu uma visita à Petrobrás e foi desobedecido. Presos alguns dirigentes, a 25 de março realizou-se uma Assembléia, durante a qual "um marinheiro denunciou ter sido torturado por oficiais e mostrou a marca de algemas e chibatadas nas costas". Neste dia, os marinheiros aprovaram as seguintes reivindicações: "1) Fim às punições e libertação de todos os presos; 2) reconhecimento da Associação; 3) humanização da marinha; 4) melhoria da alimentação nos navios e quartéis; 5) apresentação e punição dos torturadores" (Idem, p. 53). O ministro da Marinha ordenou que uma tropa do comando de Fuzileiros Navais tomasse o Sindicato dos Metalúrgicos, onde se concentravam os marinheiros, e prendesse os mesmos. No dia 26, parte da tropa de fuzileiros aderiu ao movimento. O ministro foi afastado e o seu substituto prometeu anistia a todos os rebeldes, o que estimulou o movimento dos oficiais golpistas. A 30 de março, os marinheiros ainda participaram da homenagem a João Goulart no Salão do 
Automóvel. Foi a última manifestação pública da Associação. João Cândido, sobrevivente da revolta de 1910, evento de forte tradição oral entre os marinheiros, participou destes eventos. Eles se desdobram diretamente no seu depoimento sobre 1910. Se Capitani considera a Rebelião de 1964 como a versão dos anos 60 da Revolta da Chibata (1997, p. 53), neste trabalho defender-se-á outra idéia: que o movimento de 1910 passou a ser reenfocado segundo os dilemas postos pela sociedade brasileira em 1960.

Uma outra questão deve ser dimensionada. O MIS - Museu da Imagem e do Som, foi criado em 1965 pelo ex-governador da Guanabara e um dos participantes do golpe de 1964, Carlos Lacerda. Claudia Mesquita (1998), procurando compreender as estratégias públicas na aquisição dos acervos sonoros e na coleção de depoimentos do MISRJ, propôs uma periodização de três tempos da memória carioca que estariam em disputa: no momento da criação, a memória nacional; no período de 1966-72, a memória da cidade e de 1991-94, a memória militante.

O primeiro momento seria caracterizado "pela estratégia de dotar o recém criado estado da Guanabara de uma nova identidade apontando aspectos importantes do trabalho de enquadramento da memória carioca através da criação e recriação de mitos, heróis e personagens comuns da história da cidade como sede da nação" (Mesquita, 1998, p. 473). Já o segundo momento foi o de realização dos "Depoimentos para a Posteridade", estratégia criada por Cravo Albim para garantir a sobrevivência institucional do Museu, na ocasião ameaçado de extinção devido ao corte de verbas promovido pelo Banco do Estado da Guanabara, cuja direção era nomeada pelo governo militar (Mesquita, 1998, p. 474). Segundo a autora, esta estratégia fez com que o Museu fosse legitimado como um dos espaços de maior efervescência cultural da cidade.

Este segundo aspecto é fundamental para a compreensão da dinâmica do depoimento de João Cândido, pois uma das intenções da entrevista era produzir uma imagem para a posteridade. A própria entrevista inicia-se com uma definição bastante significativa no sentido de esclarecer ao ouvinte o sentido da mesma: "Atenção: gravação para o ciclo de História Contemporânea do Museu da Imagem e do Som, realizada hoje, dia vinte e nove de março de 1968, gravação em que 
será ouvida a figura histórica de João Cândido...” (Depoimento, 1968, p. 1).

O Museu tem um interesse especial, portanto, pelas figuras definidas como históricas, e entrevistar João Cândido dentro de uma estratégia de marketing que visava salvá-lo da extinção e consagrá-lo como espaço cultural era muito importante. Ao interrogar João Cândido, o historiador Hélio Silva fez, várias vezes, referência ao fato de que "isso vai ser fixado numa fita para a posteridade. Uma fita em que os moços de amanhã, não conhecendo mais você, sem ter a menor idéia de quem eu seja, terão apenas na fixação de sua voz um depoimento... É preciso fixar quem foi este homem..." (Ibid.).

Este ideal de fixação de uma imagem de João Cândido, que percorre todo o depoimento, tem também uma outra implicação relacionada à estratégia do Museu. No momento dos governos militares, transformar o Museu em um centro cultural significava criar espaços de atuação e vivência para intelectuais e representantes de correntes políticas identificadas como populares e democráticas. Neste segundo sentido, o MIS transformou-se em um espaço de abertura que abrigava uma espécie de vanguarda cultural da cidade e do país.

Assim, a intenção de fixar uma imagem para a posteridade implicava na criação desta mesma imagem. O processo da entrevista, portanto, é ao mesmo tempo a criação da imagem de João Cândido e do Museu, ambos comprometidos com a democratização da sociedade brasileira. No caso de João Cândido, contudo, este processo não foi simples nem linear, isto porque a tensão que se estabeleceu ao longo da entrevista, a luta pelo falar e o interesse do depoente estavam voltados para outros objetivos que não os do Museu.

\section{Da condução da entrevista}

Realizada, como já visto, a 28 de março de 1968, participaram da entrevista o historiador Hélio Silva, a jornalista Dulce Alves, o superintendente e o diretor executivo do museu, respectivamente Sérgio Junqueira e Ricardo Cravo Albim. Também Adalberto Cândido, filho caçula de João Cândido esteve presente na realização do depoimento. A primeira impressão que causa a audição e a leitura do depoimento 
de João Cândido é a de que o entrevistador, ou entrevistadores, buscava informações detalhadas sobre a revolta de 1910 e sobre a atuação do então, velho marinheiro.

De fato, o entrevistador principal, Hélio Silva, realizou uma entrevista-questionário, quase um interrogatório - aliás, ele assim o denomina. O resultado é que todo o depoimento é entrecortado de perguntas e respostas. Normalmente longas perguntas e curtas respostas. Em vários momentos o entrevistador interrompe João Cândido com uma nova pergunta, sem que a resposta da primeira estivesse concluída. Em suma, os historiadores que trabalham com a metodologia da historia oral poderiam condenar veementemente o trabalho realizado nesta entrevista. Esta crítica, cuja validade metodológica não geraria dúvidas, seria, contudo anacrônica por duas razões principais. Primeiramente porque não havia no Brasil, um grande debate sobre a História Oral, ao contrário, o MIS é pioneiro neste sentido e representava uma grande novidade. Em segundo lugar, porque a crítica interditaria uma reflexão sobre o modo de construção do documento dizendo o que ele deveria ser e não permitindo compreender o que ele é e representa.

Considerando-se, no entanto, a entrevista de uma outra perspectiva, pode-se verificar que o entrevistador principal, Hélio Silva, é também o narrador principal. Através das perguntas que faz, narra a bistória da Revolta de 1910 e, ao mesmo tempo, cria, ou ao menos tenta criar, uma imagem de João Cândido. É necessário demonstrar esta afirmação. A entrevista inicia-se com as seguintes questões:

"P: João Cândido, você se tornou um nome da História do Brasil. Um nome da História mundial porque se ligou a uma causa de libertação. Há momentos em que cada um de nós pode crescer tão desmesuradamente que, com o passar do tempo, olha-se o que foi feito e parece impossível que um homem, num dado momento tenha tido essa capacidade de realização, que nesse momento, você foi um símbolo. Eu pergunto a este velho, embora um velho forte, um homem válido ainda, mas em que os anos marcaram duramente a sua passagem. Eu pergunto, primeiro lugar: você se recorda perfeitamente do que aconteceu a vinte e dois de novembro de 1910? 


\section{R: Recordo.}

P: Você, se hoje você voltasse a ser o mesmo marujo daquele dia, embora a vivência desse novo período de mais de cinqüenta anos tivesse dado a você uma longa experiência da vida e dos homens, se o João Cândido vivido de hoje voltasse a ser o João Cândido moço daquele tempo, se fosse possível esse milagre, de reunir sua experiência e a sua mocidade, você teria agido, hoje, se fosse dia dez, vinte e dois de novembro de 1910 , você teria agido como agiu?

R: Teria agido da mesma forma.

P: Bravos. Você é um homem coerente com sua vida. Agora eu pergunto então, num momento em que isso vai ser fixado numa fita para a posteridade. Uma fita em que os moços de amanhã, não conhecendo mais você, sem ter a menor idéia de quem eu seja, terão apenas na fixação de sua voz um depoimento e na minha como que um reflexo, apenas um interrogatório. O entrevistado é você. Você que deve falar. É preciso fixar quem foi este homem que passou todo este tempo e que não desapareceu nem desaparecerá. Seu nome todo: João Cândido...

R: João Cândido Felisberto.” (Depoimento, 1968, p. 1)

Como é possível se verificar, já se parte de uma definição a priori sobre o entrevistado e sobre a revolta de 1910: João Cândido é uma figura histórica e o movimento dos marinheiros uma causa de libertação. O entrevistador considera o feito do depoente - a liderança da revolta - como extraordinária, como simbólica. Isto já está definido. Ele não interroga João Cândido para conhecer a revolta, para compreender o significado que o marinheiro atribuía ao movimento nem à sua participação no mesmo. Isto o entrevistador já sabia ou imaginava saber. Buscavase pois, reforçar uma imagem já existente sobre o marinheiro e sobre a revolta de 1910.

Assim, Hélio Silva segue perguntando o nome completo, o nome dos pais, dos irmãos, quer saber quando, como e porque João Cândido ingressou na Marinha, quando foi excluído. O interessante neste processo é que Hélio Silva faz deduções que as respostas dadas por João Cândido não permitem: 
"P: Por que você entrou para a Marinha de Guerra? Você foi voluntário ou foi recruta?

R: Depois da revolta de Floriano, como houvesse falta de... de marinheiros na... na Armada. A Marinha tava esfacelada, eu fora transferido do Arsenal de Guerra, que tinha excesso de alunos, o Arsenal de Guerra de Porto Alegre, para a escola de mari... de aprendiz de marinheiros da Marinha.

P: Você tinha, portanto, ingressado na Marinha ingressando numa escola. Você era um moço pobre que queria melhorar de situação, situação inclusive intelectual. Você entrou para uma escola onde você iria aprender, e dessa escola você passou para...

R: Para a marinha." (Depoimento, 1968, p. 2).

Em nenhum momento João Cândido afirmara ser pobre ou mesmo ter ambições de ascender social, econômica ou intelectualmente. A dedução do entrevistador não encontra lastro na resposta dada pelo marinheiro. Por outro lado, como João Cândido não questiona a conclusão do entrevistador, pode-se imaginar que não discorda do mesmo ou não considerou a questão relevante.

As imagens vão se superpondo. Depois de interrogar João Cândido sobre sua exclusão da Marinha e se ele guardava queixas da Força Armada - o que foi respondido negativamente - Hélio Silva se debruça sobre a questão dos castigos corporais. O trecho é longo mas vale a pena reproduzi-lo:

"P: Em 1910, é preciso que os que no futuro ouvirem essa conversa, tenham idéia do que fez. Eu não estou tão aliado do problema. Em 1906, no dia 21 de janeiro, explodiu o encouraçado Aquidabã. No bojo deste navio ficou o corpo do meu pai, Mario Ribeiro da Silva, oficial combatente, professor da Escola Naval. Portanto, na minha infância eu me familiarizei com muitas coisas da Marinha, encontrei velhos amigos de meu pai. Mas eu estou ouvindo e aprendendo com você. Era uma tradição na Marinha de todo o mundo o castigo corporal, que foi abolido à proporção que o homem teve sentimento de sua dignidade. No Brasil, legalmente, o castigo corporal foi abolido com a proclamação da República, 
mas de fato o castigo corporal não tinha sido abolido na Marinha.

R: O terceiro decreto assinado por Deodoro foi... abolindo o castigo corporal nas Forças Armadas.

P: Mas não entrou em vigência esse artigo na Marinha. A Marinha continuava a castigar. Por que faltas eram castigados os marinheiros?

R: Pelas mínimas, mínimas faltas.

P: Não respondiam a inquérito, era coisa sumária.

R: Era só antipatia. Tomava antipatia do oficial e pronto.

P: Apenas os marinheiros ou os inferiores também eram castigados?

R: Os inferiores andavam....

P: Castigavam os sargentos?

R: ...certamente eram punidos com rebaixamentos e transferências

P: E esse castigo era feito de forma... já em si era um castigo aviltante. A prova é que a chicotada é considerado um crime com agravante, é ultrajante. Mas revestia-se esse castigo de circunstâncias mais aviltantes? Como era chicoteado o marinheiro?

R: Amarrados em... em um aparelho, um... um pau... um ferro que tem nas cobertas dos navios. Eram expostos ali, amarrados e castigados brutalmente.

P: Nus da cintura para cima?

R: Nus da cintura para cima.

P: E a marujada formada. Era um espetáculo público?

R: Era espetáculo.

P: Quer dizer, era um espetáculo de castigo físico e de degradação. E essas... Como era esse instrumento de suplício? R: Quando não eram as varas de marmelos, era uma corda intitulada.... de barca, linha de barca. E sempre os carrascos colocavam agulhas e pregos, preguinhos pequenos na ponta, coberto...

P: Esse tipo de açoite com pequenas pelas de ferro ou de pedra são destinadas a arrancar pedaços de carne. Foi o tipo de açoite com que foi flagelado Jesus Cristo (Pausa. Silêncio). 
Havia, portanto, um protesto, um movimento generalizado de repulsa a essa situação. Havia como que um estado latente. Todos eram contra ou havia alguma conspiração em curso, havia um movimento articulado para um determinado protesto ou foi uma coisa num dado momento, espontânea, que....

R: Havia, havia uma conspiração. Havia aí uma conspiração de protesto.

P: Essa conspiração pretendia...

R: E a Marinha... a Marinha seguramente sabia. A Marinha toda sabia.

P: Sei. E essa... como é que pretendiam fazer? Esperavam alguma data?

R: Esperávamos data e... poderes... Esperamos a construção dos novos navios na Europa, depois de estarmos lá há dois anos em contato com marinheiros de outras nações.

P: Esses marinheiros de outras nações, notadamente da Inglaterra, não eram mais chicoteados?

R: Não.

P: Então os marinheiros foram à Inglaterra para trazer belonaves vindas da Inglaterra, o Minas e o São Paulo, vieram de lá mais conscientes de que deviam reivindicar esse respeito à dignidade da pessoa humana.

R: Foi lá.

P: Esse foi o lucro. Portanto, nós vimos, não apenas um movimento de protesto, de defesa, de instinto de conservação contra um castigo ultrajante. Nos vimos sobretudo uma tomada de consciência.

R: Era um movimento organizado. Levamos mais de dois anos como um movimento organizado.” (Depoimento, 1968, p. 3-4)

Mais uma vez, verifica-se que é o entrevistador que define os pontos a serem confirmados. As afirmações e questionamentos de Hélio Silva - que insere o nome de seu próprio pai em um "documento para a posteridade" - compõe, portanto, uma narrativa sobre a Revolta de 1910 que João Cândido deve confirmar passo a passo. Através de Hé- 
lio Silva toma-se conhecimento de que embora a República tivesse abolido oficialmente os castigos corporais, eles continuavam a ser praticados na Armada. Esta aplicação era feita sumariamente e de modo a configurar um espetáculo supliciante. Finalmente, fica-se sabendo também que foi na Inglaterra, no contato com marinheiros da Royal Navy, que os marinheiros brasileiros tomaram consciência de que deveriam reivindicar respeito à sua dignidade enquanto pessoa. É interessante observar este esquema pois há duas questões fundamentais.

A primeira é a comparação dos castigos físicos com o suplício de Jesus Cristo ${ }^{1}$. Anos mais tarde esta associação apareceu também na música de João Bosco e Aldir Blanc: "Rubras cascatas, jorravam das costas dos santos entre cantos e chibatas". Esta santificação pode ter múltiplos significados. Um deles é o apelo à sensibilidade do ouvinte/ leitor para que este compreenda o sofrimento e a humilhação sofrida pelos marinheiros e, neste sentido, a revolta justificava-se plenamente já que estes não são como Cristo e não têm uma missão divina a cumprir na terra. Se Cristo suportou os suplícios a que foi submetido é porque isto fazia parte de um dado plano de salvação da humanidade. Já para os marinheiros não havia sentido em suportar os suplícios, daí a compreensão e a legitimidade da revolta destes homens contra atos de brutalidade dos oficiais de Marinha. Neste sentido o movimento é despolitizado. Não há uma lógica social e militar no regime disciplinar, apenas violência pura. A revolta é uma reação contra esta situação discricionária e arbitrária.

É verdade que o entrevistador conclui que houve "sobretudo uma tomada de consciência”. Mas nos termos da entrevista - esta é a segunda conseqüência - esta consciência é limitada. É a consciência da dignidade pessoal ofendida e, foi adquirida fora do país, no contato com os marinheiros ingleses. Hélio Silva, contudo, não vê esta questão como problemática e segue adiante, dentro de seu esquema, indagando sobre os acontecimentos no deflagrar da revolta, buscando esclarecer detalhes: se era verdade que as manobras com os encouraçados - que à

Dos Evangelhos Sinópticos somente Mateus $(27,26)$ e João $(19,1)$ narram que Pilatos ordenou que Jesus fosse açoitado.Segundo nota em Mateus 27,26 a flagelação era prelúdio normal da crucificação entre os romanos. Bíblia Sagrada. Stampley Ent. Inc., 1974.. 
época causaram espanto e admiração na população e na imprensa do Rio de Janeiro - eram realmente de rotina, isto é, se João Cândido foi realmente o líder da revolta, os detalhes do massacre do Satélite e da Ilha das Cobras e, finalmente as perseguições sofridas por João Cândido após sua exclusão da Marinha.

Contudo, analisando esta passagem de outra perspectiva, encontram-se elementos que permitem sugerir uma interpretação diferente daquela de Hélio Silva sobre João Cândido e sobre a revolta de 1910.

À afirmação de Hélio Silva de que o movimento representou uma tomada de consciência, João Cândido responde que "Era um movimento organizado. Levamos mais de dois anos como movimento organizado". Esta informação é bastante significativa pois permite sugerir que a revolta foi muito mais que um protesto, resultante de uma consciência de dignidade ofendida. Outras passagens do depoimento sugerem isto. Perguntado por Hélio Silva se o movimento pretendia tomar os navios e fazer um ultimato ou pretendia lançar apenas um protesto, João Cândido responde: "Não senhor, nós pretendíamos impor, impor como impusemos. Nada nos foi oferecido, nós impusemos: queremos isso e tem que se decidir por isso" (Depoimento, 1968, p. 4).

As palavras de João Cândido revelam uma consciência outra, diferente do imaginado e sabido por Hélio Silva. O marinheiro sabe que tudo dependia dele e de seus companheiros, sabia também que nada lhes fora dado, mas o que desejavam deveria ser conquistado. Se, como observa Hanna Arendt, o poder é a habilidade humana para agir em concerto, ou seja, "o poder resulta da capacidade humana de agir ou de fazer algo, como de unir-se a outros e atuar em concordância com eles" (apud Habermas, 1980, p. 110-8), pode-se compreender que a revolta foi a manifestação de um poder coletivo - que aparece nas ações e palavras dos marinheiros, evento novo sem precedentes. Fato anterior à posse dos navios, baseado na experiência do fazer-se (Thompson, 1987; 1989).

A fala do João Cândido de carne e osso "para a posteridade" revela este aspecto do fazer-se coletivo da revolta. O marinheiro vacila entre o eu e o nós, como que não querendo desapontar seu entrevistador, mas também não querendo trair seus companheiros revoltosos:

"P: E... então eu pergunto, porque este tema é muito controvertido. Desde o primeiro momento, a grande maioria 
dos autores que trataram da revolta, da revolta de João Cândido, dão a você um papel preponderante. Mas evidentemente toda medalha tem seu reverso, e houve relatórios oficiais, houve escritores que acharam que tinham exagerado a sua atuação e negaram. Houve um escritor, já falecido, que declarou que você não tinha tomado parte na revolta, que você tinha se refugiado no cesto da gávea, que fizeram você descer para comandar o navio. É uma voz isolada e eu estou apenas trazendo esse depoimento porque nós estamos depondo para a posteridade. E eu gostaria de ouvir da sua própria voz, a sua atuação neste momento: se você era o chefe da revolta dentro do navio ou se seus companheiros aclamaram você como chefe, por ser o mais indicado, o mais capaz? (...)

R: Eu tive o poder na organização da conspiração e tive o poder determinado pelos comitês para assumir a direção da revolução com todos os poderes. (....) A organização da revolta, nós... eu dispunha de todos os poderes, como dispus dentro da revolta de todos os poderes do Brasil. Parei o Brasil. Durante seis dias parei o Brasil, eu mandava na... era o Minas Gerais e o São Paulo. Era quem determinava." (Depoimento, 1968, p. 6-7).

João Cândido sabia pois que seu poder derivava, ou melhor dizendo, que ele próprio só era revoltoso e líder porque membro de um coletivo que havia optado pelo caminho da revolta. Mas este coletivo construiu mais do que isto. O manifesto dos revoltosos de $1910^{2}$ permite compreender o sentido das palavras de João Cândido. Seu teor era o seguinte:

"Rio de Janeiro, 22 de novembro de 1910.

Ilmo. e Exmo. Sr. presidente da República Brasileira, Cumpre-nos, comunicar a V.Excia. como Chefe da Nação Brasileira:

2 O original se encontra no Serviço de Documentação da Marinha. Rio de Janeiro. 
Nós, marinheiros, cidadãos brasileiros e republicanos, não podendo mais suportar a escravidão na Marinha Brasileira, a falta de proteção que a Pátria nos dá; e até então não nos chegou; rompemos o negro véu, que nos cobria aos olhos do patriótico e enganado povo. Achando-se todos os navios em nosso poder, tendo a seu bordo prisioneiros todos os Oficiais, os quais tem sido os causadores da Marinha Brasileira não ser grandiosa, porque durante vinte anos de República ainda não foi bastante para tratar-nos como cidadãos fardados em defesa da Pátria, mandamos esta honrada mensagem para que V. Excia. faça os Marinheiros Brasileiros possuirmos os direitos sagrados que as leis da República nos facilita, acabando com a desordem e nos dando outros gozos que venham engrandecer a Marinha Brasileira; bem assim como: retirar os oficiais incompetentes e indignos de servir a Nação Brasileira. Reformar o Código Imoral e Vergonhoso que nos rege, a fim de que desapareça a chibata, o bolo, e outros castigos semelhantes; aumentar o soldo pelos últimos planos do ilustre Senador José Carlos de Carvalho, educar os marinheiros que não têm competência para vestir a orgulhosa farda, mandar por em vigor a tabela de serviço diário, que a acompanha. Tem V. Excia. o prazo de 12 horas, para mandar-nos a resposta satisfatória, sob pena de ver a Pátria aniquilada. Bordo do Encouraçado São Paulo, em 22 de novembro de 1910. Nota: Não poderá ser interrompida a ida e volta do mensageiro. Marinheiros."

A análise deste precioso documento não é a finalidade deste trabalho e já foi feita em outro lugar (Arias Neto, 2001, p. 350-66). É importante observar, no entanto, que seu ocultamento do público, durante os debates políticos em 1910, configurou uma estratégia do Estado que levou à derrota da revolta. Considerando apenas seus termos principais, ou seja, as reivindicações apresentadas pelos marinheiros, verifica-se que estes pretendiam que o Estado os tratasse como cidadãos fardados em defesa da Pátria, proporcionando-lhes proteção, estendendolhes os direitos sagrados prometidos pela República, acabando com a desordem e reconhecendo-lhes a plenitude da cidadania, isto é, o direito de reivindicar: a retirada dos oficiais incompetentes, a reformulação 
dos códigos disciplinares com a extinção da chibata e outros castigos corporais, o aumento do soldo, a educação de seus companheiros mais carentes e a reforma das escalas de trabalho. Nenhuma destas reivindicações funda em si um direito novo. O que se desejava eram reformas que fortaleceriam a Armada Nacional, da qual os marinheiros consideravam-se integrantes. Estas reformas, ao cabo, incrementariam o poder do Estado, tornando mais eficaz seu instrumento de exercício da violência e de defesa externa. Nesta perspectiva, tratava-se pois, de uma revolta tipicamente militar e bastante conservadora, cujos termos parecem um eco longínquo do jacobinismo militar: a grandeza da pátria residiria no engrandecimento do soldado cidadão ou do marinheiro cidadão. Por outro lado, o movimento de 1910 demonstrou que as praças da armada eram capazes de se organizar e exigir sua participação na res publica, ou seja, nos termos do próprio documento, há a reivindicação de uma ampliação do espaço público, no qual os marinheiros pudessem expressar sua própria compreensão do sistema militar no qual estavam inseridos, bem como suas idéias para reformá-lo.

$\mathrm{Na}$ medida em que se anunciavam como cidadãos, os marinheiros falavam de um lugar que estava sendo construído, através do livre ir e vir, do pensar e de se associar, ou seja, de um exercício de construção de sua própria liberdade e cidadania. Em outras palavras os marinheiros constituíam-se como sujeitos de direitos. Esse enunciar demonstra, então, uma concepção outra de cidadania e de liberdade que não aquela fundada no direito de propriedade, mas no de igualdade política, ou seja, é porque se consideravam cidadãos que se atribuíam o direito de reivindicar. O que a revolta de 1910 enuncia então é, nada mais que o desejo de efetivação da república e, conseqüentemente, da necessidade de criação de uma carreira profissional para o marinheiro cidadão.

Através da análise do depoimento de João Cândido, pode-se perceber as implicações maiores do movimento dos marinheiros de 1910. É necessário, portanto, tentar compreender suas palavras no sentido que ele as emprega e não com o significado que o entrevistador pretendeu dar. É muito fácil confundir a revolta de 1910 como movimento por direitos humanos - conceito anacrônico em relação ao período - e movimento que construía a própria identidade de cidadania fundada na idéia de direitos republicanos, de igualdade política. A distinção é sutil, porém fundamental, pois considerando-se a priori a revolta como movimento por 
direitos humanos, perde-se a capacidade de perceber sua natureza histórica, constitutiva das noções de direitos de cidadania e de República. Perde-se pois, a dimensão característica do que se denomina contemporaneamente de movimento social.

Contudo, o próprio peso das imagens positivas (líder, herói) ou negativas (degenerado, covarde) que se impunham a João Cândido era tão grande que ele próprio oscila entre uma interpretação e outra sobre o movimento de 1910: conspiração, revolta, revolução são termos empregados, na passagem mencionada, para designá-lo. O depoente já não distingue muito bem o que o seu interlocutor desejaria ouvir. Talvez ele próprio estivesse já em dúvida sobre o "seu papel na história do Brasil". Logo após essa passagem em que se reconhecia como líder, como o homem que parou o Brasil, indagado sobre o dia a dia da revolta ele respondeu:

"Depois ao estourar o movimento, isto foi no dia vinte e dois de novembro de 1910. Primeiro aí entramos em contato com o governo do Marechal Hermes, o governo do Marechal Hermes, e então recebemos por meios telegráficos que não confabulavam com os revoltosos. Esta foi a revolta do Marechal, a resposta. Então nós resolvemos a nos fazermos ao mar, até que o governo tomasse outra atitude, nos fizemos ao mar, fomos para alto mar. Depois começou aquela confusão de ataca, não ataca, e essas coisas, e a oficialidade do Exército impunha... impunha... impuseram que o governo tinha poderes para atacar, como de fato tinha. O governo na época tinha poderes para atacar, pois tinha uma frotilha de dez destroiers novinhos, saídos da fábrica no mesmo ano... haviam mais de, mais de talvez cinqüenta torpedos com cabeça de combate preparados. O governo não atacou mesmo por negligência. Negligência e por covardia. Covardia porque o governo teve poderes para atacar, que os oficiais os... a oficialidade dispunham da teoria, não é? E os marinheiros puramente da prática e da boa vontade."

É fundamental fazer a seguinte indagação: como poderia João Cândido saber do dilema do governo se estava com os navios fora da barra do Rio de Janeiro? Como poderia ele saber que o governo tinha 
condições de atacar os navios revoltosos naquele momento? Esta não é uma narrativa do dia a dia da revolta, mas uma apreciação a posteriori dos fatos. Até o presente, as pesquisas realizadas sobre 1910 são unânimes em admitir que de fato o governo não teve condições de responder militarmente à tomada dos navios. O próprio Ministro da Marinha admitiu esta incapacidade em seu relatório de 1910. Os únicos que defenderam à época da revolta a idéia de que um ataque aos encouraçados era possível foram os próprios oficiais de Marinha e do Exército, que lançaram o duro epíteto de "covarde" ao Marechal Deodoro. João Cândido assume, pois, aqui a versão dos militares sobre este episódio. $\mathrm{Na}$ continuidade de seu depoimento relata:

"Depois entramos em contato novamente com o governo até que começaram um movimento na Câmara pela anistia. O governo enviara seu embaixador, nós não pedimos embaixador, o governo enviou seu embaixador, o deputado e capitão de mar e guerra José Carlos de Carvalho, deputado federal pelo Rio Grande do Sul. Entramos em contato e o governo propôs anistia, propôs anistia e nós aceitamos, aceitamos a anistia na boa fé, pois que vinha... vinha paralisar o movimento antes em que o pessoal se agitasse mais, que eu tinha responsabilidade de não molestar a cidade, era um dos compromissos que eu tinha. Depois de quatro ou cinco dias, já para o dia vinte e cinco ou vinte e seis, fora votada a anistia. (...) Depois eu aceitei, aceitei, de acordo com os poderes que tinha, a anistia. Indicamos os oficiais que deviam de acumular... acumular os novos postos, todos foram indicados pela revolução, pelos revoltosos, para assumir o comando dos novos navios que seriam entregues ao governo." (Depoimento, 1968, p. 12)

Mais uma vez o marinheiro oscila na caracterização do movimento como revolta ou revolução. Mas nesta passagem há dois aspectos importantes. O primeiro diz respeito à afirmação de João Cândido de que havia um compromisso em não molestar a cidade. É pertinente a indagação: compromisso com quem? Comparando esta passagem com outra anterior, do mesmo depoimento, em que João Cândido afirma enfaticamente que nada lhes fora dado, tudo fora imposto, e os próprios 
termos ameaçadores e intimidatórios do manifesto de 1910 (sob pena de ver a pátria aniquilada) a existência de um compromisso para preservar a cidade passa a representar uma novidade. Teria João Cândido feito um acordo com o embaixador do governo? Em que termos teria sido firmado este suposto acordo?

Duas suposições são possíveis. A primeira, considerando o lugar onde foi inserida a idéia do compromisso - na passagem em que se apresenta o embaixador do governo e a proposta de anistia - é que houve um acordo entre João Cândido e o deputado: a anistia seria concedida caso o Rio de Janeiro não fosse atacado. A segunda é baseada também nos termos do próprio depoimento de João Cândido. Páginas antes, ele afirmara:

"Assumi o comando da revolução com as condições tais, de poupar vida, poupar vida porque eu... o Rio de Janeiro pra mim é a minha cidade amada. Cheguei aqui como quinze anos, estou com oitenta e oito anos. Nestes setenta e três anos de idade, quer dizer, de permanência... sou um histórico 'fio' da cidade do Rio de Janeiro. Conheço a vida... vida nova e velha, seus melhoramentos, seus sofrimentos [...] eu conheço [...] conheço a cidade do Rio de Janeiro a fundo [...] e não aceito contestações." (Depoimento, 1968, p. 7-8)

Já à frente, quando o depoimento já dava sinais de saturação, pois Ricardo Cravo Albim repisava as mesmas perguntas feitas no início, travou-se o seguinte diálogo:

"P: Eu me permito, peço é, licença ao Dr... ao Dr. Hélio Silva, a lhe formular uma pergunta para esclarecer melhor os antecedentes da revolta de que o senhor foi líder. Quais os germes, como, quando o senhor entrou na Marinha, a partir de que momento passou a pensar em fazer um protesto que culminaria nessa revolta?

R: Ah, eu entrei na Marinha..

$\mathrm{P}$ : Relate isso.

R: ...entrei na Marinha com... com quatorze anos e entrei bisonho. Entrei na Marinha bisonho e toda a luz que me iluminou e me ilumina, graças a Deus, que é pouca, foi 
adquirida, posso dizer, na Marinha.

[Aqui Hélio Silva retoma a condução do depoimento]

P: Alguma vez você foi chicoteado?

R: Não senhor, graças a Deus.

P: Então você era um marinheiro de bom comportamento

R: Bom comportamento, tanto assim que seria um marinheiro, continuaria, bem, continuaria (...) várias vezes que só era permitido o engajamento nas Forças Armadas...

P: E chegou a marinheiro de primeira classe...

R: A cabo de esquadra.

P: A cabo de esquadra, o que além de um bom merecimento técnico era um bom comportamento.

R: Porém, quando dera-se a revolta, não estava exer... não era.. não era cabo, era unicamente marinheiro de primeira classe, mesmo que me convinha mais ser primeira classe do que ser cabo, que os cabos sempre têm maior responsabilidade. E de forma que toda luz que me ilumina, que é pouca, agradeço à Marinha. Cheguei no Rio de Janeiro bisonho, bisonho, não sabia nada, não sabia o "A", não sabia andar, não sabia nada. Dou graças a Deus, a esta gloriosa cidade!" (Depoimento, 1968, p. 19-20).

Estas passagens, permitem supor que João Cândido, passados 58 anos da revolta, pretendeu "deixar para a posteridade" a imagem de que ele jamais pretendera de fato bombardear o Rio de Janeiro, pois afinal de contas era sua "cidade amada". Trata-se de pacificar a história. Em 1910 João Cândido não poderia considerar-se um "histórico filho" do Rio de Janeiro. Assim, o marinheiro contribui para a construção da imagem desejada pelo entrevistador . Contudo, os eventos de 1910 não foram tão idílicos como no relato de João Cândido. Muitas testemunhas deixaram relatos e a própria imprensa noticiou amplamente o fato de que a revolta iniciou-se com o estrondo dos canhões dos encouraçados Minas Gerais e São Paulo, canhoneiro que durou toda a noite de 22 para 23 de novembro. Na Praça Quinze, no antigo Cais Pharoux as pessoas fugiram assustadas da metralha despejada pelos navios revoltosos e duas crianças foram mortas por um projétil que atingiu o morro do Castelo. João Cândido de fato omite estes episódios que em nada 
contribuem para a construção da imagem que ele próprio deseja fixar. Neste aspecto vemos a coincidência de interesses entre depoente e entrevistadores.

O segundo aspecto da passagem da página 12 que se mencionou aqui diz respeito à própria anistia. João Cândido utiliza-se desta questão para reafirmar seu papel de líder da revolta. Foi nesta condição, dispondo de todos os poderes, que ele decidiu aceitar a anistia. Também nesta passagem o marinheiro omite que houve polêmica entre os marinheiros acerca da questão. Segundo alguns relatos, a guarnição do encouraçado Deodoro teria censurado João Cândido por este ter aceitado a proposta segundo os termos do governo.

Essa necessidade de reafirmação de sua liderança é tão grande que na passagem das páginas 19-20, João Cândido afirma que era, à época da revolta, marinheiro de primeira classe porque lhe era conveniente. $\mathrm{Pa}$ rece que ele havia decidido deixar de ser cabo de esquadra. Ele omite em favor de sua imagem - que havia sido rebaixado de posto. Não interessa aqui, as razões deste rebaixamento, o importante é a omissão do fato por João Cândido. Ele poderia questionar a justeza ou não da medida, mas não o faz porque também parece querer deixar uma imagem pacificada em relação à Marinha, corporação da qual não apenas não tem queixas, como também deve toda sua "iluminação, que é pouca". Neste aspecto, contudo, o marinheiro entra em contradição, pois para satisfazer as expectativas dos entrevistadores relata todas as perseguições de que teria sido alvo após sua exclusão: não conseguiu firmar-se na marinha mercante devido sempre à pronta interferência da oficialidade naval quando estava para conseguir um novo emprego.

Esta operação de ocultamento acontece em outros momentos do depoimento. Relatando a passagem da revolta do batalhão naval na Ilha das Cobras, João Cândido narra:

"O governo fomentara a revolta na Ilha das Cobras, levantando o Regimento Naval, para daí ir ao mar e atacarem os navios, cuja tripulação estavam... já estava anistiada, para sacrificar os marinheiros. De forma em que, nós os marinheiros do Minas Gerais e dos demais navios que ainda nos conservávamos a bordo, ainda não havíamos sido excluídos, recusamos... recusamos a ... aceitamos... Tomamos aquilo como uma afronta, que os navios tava considerados já como 
desarmados. E de forma que arrebentara a revolução na Ilha das Cobras, os marinheiros que estávamos a bordo ficamos sem ação, que não tínhamos... a oficialidade que estava a bordo fugiu. Fugiu, abandonaram os navios no porto... de forma que os marinheiros novamente me confiaram o comando dos navios que haviam tomado parte na revolta, que haviam sido entregues ao governo, e foram abandonados mais uma vez pelos seus oficiais. Eu aí então levei o Minas para me proteger do bombardeio... dos bombardeios da Ilha das cobras... Então levei o Minas Gerais para ficar protegido da esquadra do governo, levei lá para a Ilha do Viana (...) E por isto, dois ou três dias sem comunicação com os oficiais de terra, eu resolvi vir ao Arsenal de Guerra, Arsenal de Marinha. E no Arsenal de Marinha fui preso, acusado de haver fomentado a segunda revolta, a preparada para o governo que era para tirar efeito da anistia concedida, e aí então seguraram o resto dos marinheiros, que a metade já tinha sido deportados, foram fuzilados em alto mar, naquele navio Satélite.” (Depoimento, 1968, p. 13)

Esta passagem demonstra mais uma vez um entendimento $a$ posteriori dos fatos. A afirmação de que a revolta do Batalhão Naval fora provocada pelo governo - explicação mais plausível ainda hoje - foi primeiramente denunciada por Irineu Machado e Rui Barbosa no Senado. Mas João Cândido não poderia saber disto naquele momento em que se encontrava isolado em meio ao conflito. Posteriormente esta visão dos fatos consolidou-se entre os escritores simpáticos à revolta. João Cândido, neste sentido, simplesmente reproduz o que ficou sabendo depois. Há contudo aqui, uma outra questão. É sabido, por todos os pesquisadores da revolta de 1910, que no momento da revolta do Batalhão Naval, o Minas Gerais, sob o comando de João Cândido, participou ao lado das forças do governo, do bombardeio da Ilha. Durante o desarmamento dos navios, após sua entrega ao governo, os marinheiros esconderam uma culatra de um dos canhões do Minas Gerais, o que propiciou aos mesmos participarem da repressão à revolta do Batalhão. Mas isto não é tudo. Vários radiogramas foram enviados do Minas para o Catete, não apenas declarando lealdade ao Marechal Hermes, mas também solicitando armamentos para que se pudesse prosseguir no 
bombardeamento da Ilha das Cobras. Foi somente em razão da ausência de resposta do governo que João Cândido decidiu retirar-se com o Minas para a Ilha do Viana. Por que João Cândido omite este importante fato em seu depoimento? Em 1912, este acontecimento foi utilizado como prova de que o marinheiro não havia fomentado a revolta do Batalhão Naval e que permanecera leal ao governo. Talvez em 1968, fosse importante "esquecer" este acontecimento em favor do reforço da imagem do líder-herói. Como poderia ser herói o marinheiro que participou da repressão de seus companheiros de farda?

Verifica-se, portanto, que o depoimento de João Cândido oscila entre suas próprias lembranças e as imagens que sobre ele foram criadas ao longo do tempo. De fato, a entrevista feita por Hélio Silva parece buscar a confirmação - pelas palavras de uma testemunha insuspeita - das conclusões do livro de Edmar Morel, A revolta da chibata, que grande polêmica causou entre os militares da Armada.

O livro $A$ revolta da chibata foi publicado pela primeira vez em 1958, pela editora Pongetti do Rio de Janeiro. Até então a maioria dos estudos sobre a revolta haviam sido escrito por militares e sustentavamse basicamente no paradigma racista, isto é, de modo bem reducionista poder-se-ia dizer que aquelas obras possuíam em comum a convicção de que a degeneração moral da raça negra explicava a eclosão da revolta. Neste sentido o livro representou uma grande novidade e de fato, promoveu, por assim dizer, uma reviravolta nos estudos sobre 1910 . Com aproximadamente 300 páginas, divididas em 14 capítulos, dos quais 10 dedicados à análise da revolta e 4 voltados exclusivamente para o personagem João Cândido, o livro de Morel é fruto de dez anos de pesquisas e investigações cuidadosas, ao longo dos quais o autor levantou documentos inéditos - em especial as referências aos casos da Ilha das Cobras e do Satélite, bem como sobre a vida de João Cândido.

Edmar Morel toma a revolta como objeto de análise histórica para fazer uma denúncia da grande injustiça sociopolítica e econômica que teria gerado a revolta e seus desdobramentos, como o massacre da Ilha das Cobras e os assassinatos perpetrados a bordo do Satélite. Na parte final do livro, acompanhou a trajetória de vida de João Cândido, que emerge da narrativa, quase épica, como um gigante, um herói "popular" da história do Brasil, símbolo das lutas sociais do povo brasileiro, mais especificamente dos negros. 
Imediatamente após a publicação de $A$ revolta da chibata os oficiais de Marinha passaram, em pronunciamentos pela imprensa, e mesmo em obras escritas, a negar as teses de Morel. O próprio Clube Naval montou uma comissão para compor uma história verdadeira e imparcial da revolta de 1910. Em 1960, o Comandante Luiz Alves de Oliveira Belo, historiador naval, encaminhou ao diretor do Serviço de Documentação da Marinha um texto preliminar, intitulado Sucintos elementos autênticos da vida do ex-marinheiro João Cândido na Marinha de Guerra entre os anos de 1895-1912. Posteriormente, Morel incorporou este texto às novas edições de seu livro. Neste documento o autor nega, ponto a ponto as teses de Morel: João Cândido aparece como um marinheiro comum, medíocre mesmo, sem nenhuma qualificação. Segundo Belo que apenas repete os argumentos dos escritos militares dos anos 1910 e 1920, não houve nada de extraordinário nas manobras dos encouraçados quando sob domínio dos marinheiros. E, ex silentio afirma que João Cândido - sendo degenerado como os de sua raça - era um covarde e sequer teria liderado de fato a revolta de 1910.

É, portanto, a sombra deste debate onde se contrapunham imagens opostas, um dos elementos que permite compreender a entrevista de 1968. Hélio Silva, procurava afinal, através do testemunho do próprio João Cândido, desmontar a imagem veiculada pelos escritores militares da Armada. Assim, para ele pouco importava de fato o que João Cândido - de carne e osso - pudesse pensar ou dizer, o fundamental era confirmar a veracidade da imagem de João Cândido constituída pelos escritores de tendências esquerdistas. Por isto a entrevista causa uma sensação de dejà vu, já que o narrador Hélio Silva obedece, ponto a ponto, o esquema traçado no livro de Edmar Morel. Contudo, como se viu, João Cândido, às vezes confuso com suas próprias imagens e suas lembranças, termina por assumir outras versões e por revelar aspectos de sua própria pessoa até então desconhecidos.

\section{Dos resultados do processo}

A entrevista toda é conflituosa. De um lado há as expectativas institucionais do Museu (registrar o documento de uma figura histórica) presente através de seus representantes e do entrevistador (obter a confirmação 
daquilo que ele já sabe sobre 1910) e de outro as expectativas de João Cândido. Estas parecem ser muitas. Em primeiro lugar, o próprio desejo de ser reconhecido, de deixar seu depoimento para a posteridade através de uma fita, argumento empregado constantemente pelo próprio entrevistador. E, como decorrência disto, há como que um temor de João Cândido em desapontar o entrevistador, os representantes do museu e seu próprio filho, emitindo uma opinião diferente daquela já previamente enunciada na pergunta feita, pois isto poderia "invalidar" o depoimento.

Estas várias relações de poder geraram um surdo conflito entre depoente e entrevistador, que ao cabo resultou de fato na ausência de comunicação. Parece paradoxal falar em ausência de comunicação em um depoimento gravado, mas se esperava que a fala do João Cândido - de carne e osso - fosse apenas um eco de outra fala: a que reproduzia a imagem do João Cândido mítico, imagem construída pelos autores de tendências esquerdistas. Há assim um hiato entre perguntas e respostas preenchido pelos desvios da fala de João Cândido, nos quais manifesta seu militarismo e seu nacionalismo ufanista.

Nestes desvãos revela-se o João Cândido militar, que revoltoso em 1910, integralista nos anos 1930, de um lado condena a revolta dos marinheiros de 1964 e considera o golpe como medida de salvação pública:

"P: Você sempre foi um homem que tomou partido, que tomou uma atitude, o partido dos humilhados, o partido da libertação. Certo?

R: O partido dos bons.

P: O partido dos bons. Muito bem. Agora eu pergunto: nesse período, do seu desligamento da Marinha, de 1912 até agora, o Brasil passou por várias crises políticas, teve vários movimentos. Sem querer fazer uma apreciação política, mas apenas definindo sua conduta, como um homem que tem um lugar na História do Brasil. Nesses períodos todos, você como considerou ou como se portou em face desses movimentos sucessivos, vamos dizer 22, 24, 30, 32, 37, 38, 45, 54 até os dias de hoje?

R: Daqueles primeiros movimentos de 22 e 24, daqueles eu tenho pouca... eu tenho pouca prática. Porém este, este 
movimento dos marinheiros... os marinheiros me consultaram e eu avisei a eles que eles iam cair do galho, que a ocasião era inoportuna.

P: Refere-se a 38?

R: Estes agora... dos marinheiros de... de 64. 64? Eu avisei a eles: vocês vão cair do galho. Nunca me pediram opinião, porém eu que já sabia de tudo avisei a eles. De fato, entusias... entusiasmaram-se demais. E este agora, esse militar, desculpem as minhas expressões, eu sei que os paisanos vão ficar zangados comigo. Foram um movimento de salvação pública, na minha opinião. Não sei se alguém vai discordar de mim. Este agora, os militares, foi um movimento de salvação pública porque eles estão trabalhando. Eles estão, os militares estão trabalhando. Bem que também que eles estão rodeados de boas equipes. Eles estão trabalhando, se não fizerem tudo, farão o que puderem. E nós paisanos já devíamos ter feito o que eles pretendem fazerem agora. Esse movimento, sede bem vindo, que foi um movimento de salvação pública. (...) Eu quero, eu quero ver é um Brasil bom, grande, forte, defendendo os seus, dando fartura aos seus, sem pedir, sem precisar de pedir trigo lá na Rússia, na Argentina, nesses lugar, que nós temos capacidade para tudo isso..." (Depoimento, 1968, p. 21-2)

Diante de tão inesperada apreciação dos fatos políticos recentes, que contrariava frontalmente a expectativa que se tinha do herói - daquele que sempre tomou o partido da libertação, dos bons - o entrevistador voltou ao tema da revolta de 1910 e o depoimento começou a repetir-se e a saturar-se, descrevendo um movimento circular que se rompeu ao final, com uma mensagem de João Cândido para o futuro: "É perciso que trabalhamos muito, que haja muita união, parte com parte, que desapareçam as paixões, os espíritos de vingança [...], é perciso que estejamos unidos para o futuro [...] a rapaziada, a mocidade, os jovens de hoje [...] é perciso muito trabalho, muita união, muito espírito de irmandade." (Idem, p. 30)

Essa não correspondência entre o que se desejava e o que foi, talvez tenha decidido a fortuna do depoimento de João Cândido. Como o manifesto de 1910, a fala do "Almirante Negro" não poderia 
ser enquadrada claramente em nenhuma tendência política quer à esquerda, quer à direita, assim como não se ajustaria a nenhum modelo historiográfico em voga naqueles anos de chumbo. Deste modo à censura dos conservadores somou-se a desilusão dos "progressistas". Os primeiros, como faziam desde 1910 , tentaram silenciar os ecos da revolta dos marinheiros e da voz de João Cândido. Os segundos seguiram, após 1974, cantando o "Mestre Sala dos Mares", preferindo assim a imagem do herói à fala de João Cândido. Também estes quanto mais cantavam o movimento em prosa e verso, contribuíram, talvez até mais que os conservadores, para silenciar as vozes de 1910 e de 1968.

O depoimento permaneceu assim depositado no MIS, abandonado por décadas. Porém, como a Revolta de 1910 e como o próprio João Cândido, ele continua a desafiar o esquecimento, o silêncio e a historiografia. Isto porque a imagem do herói é um referencial para os marinheiros em busca da anistia e para os negros em busca de reconhecimento na sociedade brasileira contemporânea. E a imagem do herói não pode ser evocada sem provocar polêmica. Não apenas porque existirão oficiais da Armada prontos a negá-la, mas principalmente porque João Cândido é contraditório em seus sentimentos, palavras e ações, ou seja, possui as características inerentes à condição e à historicidade humanas que a imagem de um herói não suporta.

Agradecimentos:

Agradeço à Comandante Maria Rosangela da Cunha do Serviço de Documentação da Marinha pela cessão de cópia do depoimento gravado de João Cândido, a Adalberto Cândido pela permissão concedida para a utilização do mesmo depoimento e a Claudiomar dos Reis Gonçalves, da Universidade de Londrina, pelas críticas e sugestões.

\section{Referências bibliográficas}

ARIAS NETO, José Miguel. Em busca da cidadania: praças da Armada Nacional 1867-1910. (Tese de Doutoramento). São Paulo: FFLCH-USP, 2001.

BLOCH, Marc. Introdução à história. Lisboa: Europa-América, 1997.

CERTEAU, Michel de. A escrita da História. Rio de Janeiro: Forense-Universitória, 1982. 
CAPITANI, Avelino B. A rebelião dos Marinheiros. Porto Alegre: Artes e OfíciOS, 1997.

FOUCAULT, Michel. A arqueologia do saber. 4 ed. Rio de Janeiro: ForenseUniversitária, 1995.

HABERMAS, J. O conceito de poder em Hannah Arendt. In FREITAG, Barbara \& ROUANET, Sérgio P. Habermas: sociologia. São Paulo: Ática, 1980.

JANOTTI, Maria de L. M. A falsa dialética: Justiniano José da Rocha. Revista Brasileira de História. São Paulo, v. 3, nº 2, p.3-17, março, 1982.

LE GOFF, Jacques. Documento/Monumento. In: Enciclopédia Einaudi. Lisboa: Imprensa Nacional/ Casa da Moeda, 1984, v. 1.

MESQUITA, Claudia Cristina de. Três tempos da memória carioca em disputa: uma discussão sobre as estratégias públicas na aquisição dos acervos de registros sonoros e da coleção de depoimentos do Museu da Imagem e do Som do Rio de Janeiro (MIS/RJ) e a construção da identidade carioca (1960/65, 1966/72, 1991/95). In: X International Oral History Conference: proceedings. Rio de Janeiro: CPDOC/FGV, FIOCRUZ, Casa de Oswaldo Cruz, 1998, v. 1, p. 470-76.

THOMPSON, E.P. Tradición, revuelta y consciencia de clase. Barcelona: Editorial Crítica, 1989.

A formação da classe operária inglesa. Rio de Janeiro: Paz e Terra, 1987, (3 v.).

Resumo: Este texto pretende analisar o processo de construção da entrevista concedida por João Cândido ao Museu da Imagem e do Som do Rio de Janeiro. Tratando a referida entrevista como documento/monumento, procurar-se-á demonstrar o significado histórico de sua realização em 1968, bem como seu lugar no conjunto da historiografia da revolta de 1910.

Palavras-chave: política; sistema militar; movimentos sociais; marinheiros nacionais.

JoÃo CÂndido 1910-1968: archaelogy of a testimony about the Revolta dos MARINHEIROS

Abstract: This paper intends to analyze the building process of João Cândido's interview at Image and Sound Museum of Rio de Janeiro. We'll consider this interview as a document/monument to demonstre the historical meaning of its accomplishment as well as where, in the historiographical knowledge about 1910 Revolt, it took place.

Key words: politics; military system; social movements; national mariners. 